\title{
CONSIDERATIONS REGARDING THE MORLACHS MIGRATIONS FROM DALMATIA TO ISTRIA AND THE VENETIAN SETTLEMENT POLICY DURING THE 16TH CENTURY
}

\author{
DANA CACIUR
}

\begin{abstract}
The Turkish offensive in the Balkans often determined various human groups to search for a new life outside the borders of the Ottoman Empire. In the Dalmatian hinterland, administrated by Venice since the beginning of $16^{\text {th }}$ century, the Morlachs are those who, together with Serbians, Croatians, Bosnians, etc. chose to accept the Venetian protection against the non-Christian danger.

On its side, St. Mark's Republic needed more and more new people to repopulate various regions that had hardly been affected by wars, plagues and drought. During the $16^{\text {th }}$ century Serenissima established the rules of internal migrations (from one region to another of Stato da Mar) and its settlement policy for the poorly habited areas and their new colonists.

The encouragement and the development of the population transfer from Dalmatia to Istria represented an aspect of the Venetian policy in balancing the demography of the state. Arrived from the inner Balkans, the Morlachs accepted quite often to settle in south - western Istria, because the benefits and the exemptions offered by the Republic were not to be ignored: exemptions from fees for using public pasturelands, the right to build settlements in empty spaces, exemptions from fees for transport or reductions from some of the administrative taxes. Even if these benefits were temporary or permanent, they used to increase the number of Morlach migrations from Dalmatia in Istria. In effect, as the documents attest, during the $16^{\text {th }}$ century plenty of Morlach settlements appeared in the hinterland of the Istrian cities, like: Rovigno, Umago, Pinguente, Montona, Cittanova, Villanova, Raspo, Parenzo etc. Despite the fact that sometimes the Morlachs chose to leave the new settlements and turn back in Turchia, the numerous settlements colonized and inhabited by them justify, up to some extent, the existence of an Istrian Morlacchia.
\end{abstract}

Dana Caciur, PhD student, University of Bucharest, Faculty of History, B-dul Regina Elisabeta 4-12, sector 5, cod 030018, Bucureşti, Romania, e-mail: caciur_silvia@yahoo.com

Key words: Morlachs, Dalmatia, Istria, settlement policy, spontaneous and organized migrations, privileges, obligations.

DOI: http://dx.doi.org/10.14746/bp.2015.22.5

The Queen of a vast Empire placed mostly over the sea, the Most Serene Republic of St. Mark faced specific challenges in its administrative policy. The present argument aims to highlight the manner in which Venice turned in its favour the Ottoman offensive toward Dalmatia and the territorial losses caused by it. The main consequences of the Ottoman advancement affected the Venetian Dalmatia equally by reducing its hinterland, the demography and the economic potential of the region, but also by bringing new subjects, refugees from the new Ottoman conquered territo- 
ries $^{1}$. These new inhabitants (novi habitanti ${ }^{2}$ ) were soon as possible included in the Venetian administrated communities and learned to respect and obey the Venetian political system. The most appropriate solution applied by the Republic proved to be the settlement of these newly arrived inhabitants in those areas strongly affected by war, plague and drought. For the $16^{\text {th }}$ century this settlement policy and its Venetian particularities can be exemplified with the settlement of the Dalmatian Morlachs in the depopulated regions of Istria.

Pushed away by the numerous damages caused during the Turkish offensive but also because of the generous promises made by Venice, a great number of Morlachs chose to come from beyond the Dalmatian border and to settle in the Venetian territory and became the subjects of Serenissima. Although, since Dalmatia lost more and more from its hinterland and the waves of immigrants were more frequent, Venice decided to transfer some of these groups in Istria. Here again, the hinterland was strongly affected by the war with the House of Austria, drought and plague, but it allowed the settlement of new inhabitants. Beginning with the $16^{\text {th }}$ century this transfer of people from Dalmatia in Istria was practiced more systematic and well organized, based on a very attractive settlement policy. Once the military conflicts between the members of the Cambrai League were over and the borders were established in Istria, Venice then began to focus on how it should repopulate the region, revitalize the agriculture and assure the protection of the border ${ }^{3}$. Considering the difficult situation from Dalmatia, where the new inhabitants challenged the administration, already confronted with the problem of a reduced territory, the loss of a large population and the permanent Ottoman threat, the Republic facilitated the transfer to Istria, with its own ships, of numerous groups of Serbians, Bosnians and Morlachs. Together with them Venice also settled in Istria various refugee groups from Malvasia, Nauplia di Romania, Cyprus and Levant. From all of these the Morlachs proved to be the group that responded the best to the Venetian policy ${ }^{4}$ even if they sabotaged it whenever they found the opportunity. However, the Morlachs did not prevent the Republic in achieving its goals, but encouraged it to develop a set of means that allowed Serenessima to control the Morlachs. The direct contacts existing between the Morlachs and the Venetian Republic in Dalmatia since the middle of $14^{\text {th }}$ century created for Venice the opportunity of understanding what the Morlachs liked the most. Thus, by offering to the Morlachs economic, social and political advantages and also some autonomy, Venice attracted different Morlach groups on its side and managed to use them in revitalizing the emptied Istrian provinces.

\footnotetext{
${ }^{1}$ Antolini, Nicola, Slavi e Latini in Istria tra cinquecento e novecento: origine storiche e problemi del contesto multi-etnico istriano, in "Storicamente", 2 (2006), http://www.Storicamente.org/02antoli ni.htm.

2 Antolini, Slavi e Latini in Istria.

${ }^{3}$ Lia de Luca, Venezia e le immigrazioni in Istria nel Cinque e Seicento, $\mathrm{PhD}$ thesis, unpublished, defended at $\mathrm{Ca}^{\prime}$ Foscari University, Venice, 2011, p. 19.

${ }^{4}$ Lia de Luca, Venezia e le immigrationi, 23.
} 
In addition to that, the large number of Morlachs and their privileged status gave birth to an interesting socio - ethnical situation: many from the other Slavic communities colonized in Istria were assimilated by Morlachs and identified with the Morlach name. This way, during the $16^{\text {th }}$ century there is the basis for Morlacchia Istriana ${ }^{5}$. The name can be disputed if one is to consider the ethnic origins of this Istrian Morlach community and also if we compare it with the specifics of "the other countries of the Morlachs ${ }^{6}$ " placed beyond the border of Dalmatia. Though, the name Morlacchia Istriana is representative in identifying the region in which Venice applied its settlement policy. On the other side, this name can suggest the evolution and the consequences of the settlement strategies and also the identification of some elements that kept alive Morlach characteristics which faded away, more and more, in Dalmatia.

To justify the previous hypothesis it is necessary to observe what implied the Venetian settlement policy and how it worked in the case of the Morlach colonization of Istria. In reaching this goal I will present the main waves of the Morlach migration in Istria, followed by a short case study on how the population transfer was realized during 1539 - 1540 and how these Morlachs were settled in the territory of Rovigno and Parenzo.

Concerning the main waves of the Morlach migration from Dalmatia in Istria in the period before the Cyprus war can be formed the next chronological list:

- 1520: Morlach refugees are mentioned in Rovigno and Canizza d'Arsa ${ }^{7}$

- 1525: The Republic approved territorial concessions to a group of Morlach families, to form two new villages in the territory of Rovigno and Parenzo ${ }^{8}$. The Morlachs settled in the hinterland of Parenzo and named their new village Villanova and recognized the authority of the Podesta of Parenz ${ }^{9}$ o. The other group settled in the hinterland of Rovigno and named their village, Villanova. Built in the valley of Lake Verzo $^{10}$ this village obtained official recognition one year later ${ }^{11}$.

- 1539: A new wave of immigrants arrived in the territory of Parenzo increasing the number of Morlach families to 60 . According to some documents issued by the Venetian Senate, 2000 new families ${ }^{12}$ were settled in this area.

\footnotetext{
5 Antolini, Slavi e Latini in Istria.

${ }^{6}$ Morlacchia placed during the $15^{\text {th }}$ century in the territory of Imotski, and the Morlacca identified with the Velebit's slopes and lived by Uskoks.

7 Apud D. Alberi, Istria. Storia, Arte, Cultura, Trieste, 1997.

${ }^{8}$ Lia de Luca, Venezia e le immigrazioni, 18.

${ }^{9}$ Schiavuzzi Bernardo, Cenni storici sull' etnografia dell' Istria, in "Atti e memorie della società Istriana di Archeologia e storia patria, vol XVIII, facs. no. 1 and 2, Parenze, 1901, p. 93.

${ }^{10}$ Schiavuzzi, Cenni storici sull' etnografia, 93.

${ }^{11}$ Lia de Luca, Venezia e le immigrazioni, 53.

12 Lia de Luca, Venezia e le immigrazioni, 53.
} 
- at the end of the $4^{\text {th }}$ decade: Some Morlach communities were present in the territory of Montona. Here they were colonized in villages named: Montreo, San Giovani della Cisterna and Mondellebotte. This new immigrants also settled in San Lorenzo and Cittanova ${ }^{13}$.

- 1540: Morlachs, Albanians and Greeks colonized around Umago, Buie, Pinguente, Montona şi Cittanova ${ }^{14}$. These Morlachs seemed to be a part of those 2,000 Morlach families brought to Istria in $1539^{15}$.

- 1556: Morlachs near Villanova and Leme ${ }^{16}$

- 1558: Morlach families came from Dalmatia and were settled in small villages around S. Lorenzo del Pasentico. Together with other villages where Morlachs were settled in 1556: Pascotich, Dunsan, Descovich, Gardevich, Cossulich, Rupenovich, Vratovich şi Grubarevich, they formed a new village named Villanova ${ }^{17}$

- 1566: Inhabitants from the Venetian Dalmatia, Morlachs and Montenegrins are mentioned near Villanova, Leme and the surrounding territories. ${ }^{18}$

- 1570: Morlachs near Varvari ${ }^{19}$

Analysing this list we can observe that around the years 1539 - 1540 a very large number of Morlachs arrived in Istria and were settled in various regions. Below I will present who these Morlachs were, where did they come from and how they were settled in Istria. Their example can be used as a pattern for the other waves of Morlach migrations in Istria, as an applied form of the Venetian settlement policy.

According to the documents discovered in the archives of Senato Deliberazioni Mar and Secreti from Archivio di Stato di Venezia this migration of Morlachs from Turkish territory to the Venetian lands can be dated somewhere between $3^{\text {rd }}$ May $1538^{20}$ when Alvise Badoer was named Provveditore generale for Zara - Zadar and Dalmatia and $22^{\text {nd }}$ October of the same year ${ }^{21}$ when the Venetian Senate congratulated Badoer and Camillo Orsino, general governor of Dalmatia for facilitating this transfer of population. Even if many other persons were involved in this arrival of new subjects to Venetian territory, Alvise Badoer earned and maintained the main role in the operation. Many documents related to the privileges, exemptions or other kinds of benefits requested by or offered to the Morlachs colonized in Istria, often recall

${ }^{13}$ Lia de Luca, Venezia e le immigrazioni, 54.

14 Apud Alberi, Istria.

15 Cigui, Rino, Alcuni aspetti della vita socio-economica a Umago nei secoli XVI e XVI, in "Histria", vol. 3, Pula, 2013, p. 53.

16 Apud Alberi, Istria.

17 Schiavuzzi, Cenni storici sull' etnografia, 98.

18 Apud Alberi, Istria.

19 Apud Alberi, Istria.

20 Archivio di Stato di Venezia (further: ASV), Senato Deliberazioni Secreti, registro nr 59, pp. 40 $40 \mathrm{v}$.

21 ASV, Senato Deliberationi Secreti, registro, nr 59, pp 93v-94r. 
that Alvise Badoer was the one who "removed them from Turks" and brought them "in the shadow of Serenissima". His role is although predestined by the tasks he received when he left Venice. Together with utility tasks (to build and repair the walls of Zara and other places in its hinterland) and financial tasks (to organize the funds for the construction work and guards payment), Alvise Badoer had the duty to transfer "from all the territories and lands of Dalmatia all those who ask to be removed, women, children and other useless persons, keeping in Dalmatia only those able to fight" 22 . This duty was designated to Badoer as a response to the request of the ambassadors from Zara who required the right of transferring the population affected by the Ottoman offensive.

However, beautiful words and promises of wealth receive not only the Venetian officials involved in this organized migration of Morlachs in the Venetian territories, but also the Morlachs themselves. Already in 1538, the rettors of Zara had to notify "those cathonari and their other leaders" about the great "pleasure they produced to Serenissima, for which reason they will be hold close to it and will not miss any of those things they need ${ }^{23}$ ". In addition to that, "if any of them decide to appear in front of us they will be welcome". No later than December of the same year, in front of the Senate arrived three Morlach leaders, "the main authors of this Morlach transfer" 24 . These three leaders seemed to know how Serenissima used to reward those who did well for the Republic, so they appeared in front of the Senate demanding compensation for their "good actions". The members of the Senate decided to provide Sacman Gliegevaz, the most important of those three leaders, with 10 Venetian ducats, and the other two, Paulo Haycinovich and Piero Nacinovich with 9 ducats each. Also, 100 cechini were granted to provide the Morlach leaders with the clothes necessary for the journey back in Dalmatia and to pay for the costs of the journey.

What did this demographic increase for Venice mean? Most of the time, the documents summarized the "joy" of Venice with "the great damage produced by the enemy and the great amount of good done to that province and to our causes ${ }^{25}$ ". However, the benefits were quite numerous. The document of 7th December 1538 informed about a "large number of animals, big and small, which the Morlachs brought with them" and about the "damage they inflicted on the Turks", since the Morlachs were those "who waged war in the vicinity of Zara" ${ }^{26 ", ~ t h u s ~ b e i n g ~ v e r y ~ u s e f u l ~ f o r ~ t h e ~ p r o-~}$

22 ASV, Senato Deliberazioni Secreti, registro nr 59, pp. 40 - 40v: Et per che li ambasatori di quella fidelissima comunita nostra di Zara ne hano dimandato che vogliamo concederli licentia che possono mandare in questa citta o in quell'altro loco nostro che li parera le donne, le putti et altre persone inutile siamo contenti che li dii bona licentia di farle, et il medesimo ti dicemo di tutte le altre terre et loci di Dalmatia che rechiedesseno de poter mandar via le donne, puti, et altre persone inutile facendo pero che restino li homeni da fatti.

23 ASV, Senato Deliberationi Secreti, registro nr 59, pp 93v - 94r.

24 ASV, Senato Deliberation Mar, registro 24, p. 179 v.

25 ASV, Senato Deliberationi Secreti, registro nr 39, pp 93v - 94r.

${ }^{26}$ ASV, Senato Deliberation Mar, registro 24, p. 179 v: che numero et che sorte di genete murlacha dalla obedientia del turco sia venuta alla devotione della Serenita Nostra in che modo ella si e passata ad habitare nella iurisditione soa, et con qual utile, et beneficio delli territorii, se per il rispetto del- 
tection of the border. The arrival of the Morlachs in a territory devastated by military operations and abandoned by the old inhabitants, offered an unexpected solution for Venetians in maintaining the border region to be populated and cultivated. Because of that, the Venetian authorities understood how "important it is that Morlachs live in that territory now inhabited by such a small number of people ${ }^{27}$ ". The inspector for Dalmatia and Albania, Giovanni Battista Giustinan, considered the main reason for the removal of the Morlachs from Turkish territories, to be the need to keep alive the agriculture of the region. Thus, in his report describing the rural situation of Zara, Giustinian said that "this region has few inhabitants, but when there were more people the lands used to produce a large quantity of grain and wine, not like in present times when the land is uncultivated, because there is nobody to work on it ${ }^{28}$ ". According to him, since the agricultural lands were uncultivated, they could not offer any more what the citizens of Zara needed for their lives, only the Istrians and the Morlachs could survive there, "Istrians were brought there by Alvise Badoer from the Turkish territories, during the last war with the Turks (..) to cultivate those lands" 29 .

But, who were these subjects that were removed from the Turkish territory? A document from $22^{\text {nd }}$ October 1538 speaks about Turkish subjects brought from "Murlacha with their sons, wives, animals and other personal things 30 ". A document from $29^{\text {th }}$ January $1540^{31}$ offers more detailed information regarding the place from where the Morlachs came from. According to it the Morlachs came from Banadego. A few years later, in his report Antonio da Mula completed the image. Thus, in 1538 Alvise Badoer stated "from Banadego, a Turkish territory, to the devotion for Serenissima, around 5,000 Morlach souls ${ }^{32}$ came”. In similar ways the events other Venetian officials are described in charge of various offices in Zara and Dalmatia. So

\footnotetext{
le persone loro, come del numero grande di animali grosii et minuti, che hanno condutto seco, per il che non accade hora altramente narrarlo, ma solo dire che cognoscendo oltra di cio il ditto proveditor il danno, che si faceva alli inimici, levandosegli questa gente, qual era in gran parte quella che faceva et teneva la guerra vicina a Zara.

${ }^{27}$ ASV, Senato Deliberationi Secreti, registro 66, pp 104v - 105r.

${ }^{28}$ Itinerario di Giovani Battista Giustiniano sindico in Dalmazia ed Albania 1553, in "Commissiones et relationes", tom II (1527 - 1553), Zagreb, 1877, p. 198: questo territorio ha pochi habitanti, e quando fossero in maggior numero si caveria assai maggior quantiàdi biavi et vini, che non si cava al presente, per non essere lavorate le terre, le quali restano incolte. Onde il territorio per questa cagione non dà da vivere al paese ma Istriani e Murlachi, li quali Istriani al tempo dell'ultima guerra turchesca per opera, astuzia et valore del clarissimo misser Alvise Badoer allora proveditor general in quela provincia aveva condotti dal paese del Turco, per coltivar quel paese.

${ }^{29}$ Itinerario di Giovani Battista Giustiniano sindico in Dalmazia ed Albania 1553, in "Commissiones et relationes", tom II (1527 - 1553), Zagreb, 1877, p. 198.

${ }^{30}$ ASV, Senato Deliberationi Secreti, registro, 59, pp. 93v - 94r: operatione per voi fatta de condur dalla obedientia dei Turchi alla devotion nostra quelli subditi Turcheschi della Murlaccha, con li figlioli, donne, animali, et altri beni soi.

${ }^{31}$ ASV, Senato Deliberationi Secreti, registro 61, pp. 63v - 64r.

32 Relazione di Zara di M. Antonio da Mula, 1543, in "Commissiones et relationes Venete", tom II (1527-1553), Zagreb, 1877, p. 173.
} 
does Antonio Diedo ${ }^{33}$ who reported the fact that the few inhabitants from Zaras' lands were "those foreigners, Istrians and Morlachs, removed from the Turkish territory, during the last war, through the decision of Alvise Badoer"; and again, similar things were reported by the former captain of Zara, Paolo Justinian who showed compassion for the lands of Zara "which without those men removed by Alvise Badoer from the Turks, being around 1,000 fires" "would have probably remained depopulated" 34 . The Morlachs themselves help us to reconstruct the events. As a result of the "prudent, skilful and honest" persuasion of Alvise Badoer, the Morlachs promised "to live and die in the shadow of this Serenissim State" ${ }^{35}$. Together with other information regarding some complaints and demands, the Morlachs' document mentioned a number of "2,000 fires" that "abandoned their important status" offered to them by the Turks and "recognized willingly and freely their devotion for the Venetian Signoria and the Illustrious Doge 36 ".

The adventure of the Morlachs of Alvise Badoer continues, though, with a new phase. Mentioned for the first time in 1543, this phase is important for us because provides an explanation of the name of the Istrian Morlachs (Morlachi Istriani), as a group settled in the border region of Zara that claimed themselves from the Morlachs transferred by Badoer. This information appears in the report of the former inspector of Zara, Antonio da Mula. He described how Alvise Badoer facilitated the migration of the Morlachs from Banadego in the Venetian territory, and from there in Istria; but the inspector informs that sometime before $29^{\text {th }}$ January 1540 (the first exemption offered to the Morlachs to avoid their return in Turchia) the Morlachs had returned to Turkish territory. The reason for this return is given by the "bad agricultural lands, small pasturelands, the water deficiency and the damage caused by the Turks" 37 . Of course, not all of them returned to their old nest (il nostro nido antiquo). Various numbers of Morlachs mentioned in documents can offer a perspective over the different evolutions of different groups of Morlachs split from the group brought by Alvise

33 Relatione del sindicato di Dalmazia ed Albania nell'ecc. Senato per il magnifico messer Antonio Diedo (codice del sec XVII), in "Commissiones et relationes Venete", tom III (1525 - 1571), pp. 18 - 19.

34 Relatio viri nobilis domini Pauli Justiniani reversi capitanei Jadrae, presentata die 12 februarii 1553, in "Commissiones et relationes", tom III, pp. 51 - 52.

35 ASV, Senato Deliberazioni Mar, filze 6, p. 409, whitout date, but the box has only documents dated in 1569: (...) havendo delibato di viver et morir sotto l'ombra di questo Serenissimo Dominio et perho noi nuntii prefatti riverentemente dicevo a Vostra Serenita che detti Murlachi al tempo che stavano in Turchia et che erano servi, overo membri principali delli confini turcheschi di Dalmatia erano da doa millia fuoghi et in ogni importante factioni et imprese che li turchi haveano da far voleriano che noi Murlachi fusamo li prima come e noto regulo per esser molto ben noto a Turchi la probita et valor nostro nella guerra. Ma venuto il clarissimo miser Alvise Bdoer proveditor general in Dalmatia al tempo della guerra turchescha et cognosciuto per sua magnificentia di quanto honor et utile era a questo iinuisentissimo dominio il potter redure noi Murlachi alla devotione sua si opera con ogni haver prudentia, desterita et integro suo a persuaderni et inducni a abandonar le oppulennte faculta nostra et venir come in effecto voluntariamente et perinstavole venisero alla devotione di Vostra Serenita et di questo Illustrissimo Doge.

36 ASV, Senato Deliberazioni Mar, filze 6, p. 409.

37 Relazione di Zara di M. Antonio da Mula, 1543, in "Commissiones et relationes Venete", tom II (1527 - 1553), Zagreb, 1877, p. 173. 
Badoer. This way, 4 major Morlach groups can be identified: one group that remained in the territory of Zara; one group transferred and settled in Istria; one group that returned to Turkish territory (a group that probably engaged also Morlachs from the region of Zara); and one group that left Istria and settled in the region of Zara. Thus, the Istrians or the Istrian Morlachs present in the border region can be a result of the spontaneous movement of these 4 groups or of their mixing.

Considering the Morlachs that remained in Istria their settlement process can be observed thanks to a document issued in May 1539. According to this document a number of "2,000 houses of Morlachs (from those brought by Alvise Badoer from Banadego) desiring to live in our place of Istria" are mentioned asking the Senate for "some things useful for their life and comfort" ${ }^{38}$. For these Morlachs colonized in Istria the Senate offered the possibility to equalize their fortune abandoned in the Turkish territory, as it was considered legal and necessary. To become "perpetual settlers and inhabitants in the rural territories and other places of Istria" the Morlachs were exempt from the payment of pasturelands "like other perpetual settlers from Istria". The Morlachs received the right to build houses "in the manner and form they can" in the empty places "outside the cities and castles of Istria, in rural lands (..) like other subjects living in the region". Also, to help them to "take care of their animals, to easily plough and cultivate the vineyards, and to facilitate their settlement in the region" the Morlachs "are exempt for two years from any obligation in paying the transport and not only, that might be required to other subjects". Also, the authorities had to show them a positive attitude (to pamper them) and not force them to pay "for the secretaries, knights or other functionaries more than 8 soldi each, according to the law and tradition of the region and understanding 8 soldi from each head of family ${ }^{39 "}$.

The exemptions offered by Venice to the Morlachs settled in 1539 in Istria can be seen as an applied form of the Venetian settlement policy. The historian F. C. Lane describes this policy as "a tradition derived from the Venetian habit of including in his social and economic structure necessary productive elements; for the Istrian context, Venice should have been tried to introduce, by all means, new elements in the rural world, hardly depopulated, especially in the South of the region ${ }^{40}$ ". In this way, the Morlachs removed by Alvise Badoer from the Turkish territory in Zara's region and after that in Istria, became a part of the colonizing process in which Venice engaged numerous groups of Serbians, Croatians, Greeks, and others.

Two decades later, in October 1557, the Morlachs who colonized Istria in 1539 sent to Venice, to the Doge, a set of 8 requests that meant to facilitate their life. According to this document, about 60 houses of the Morlachs were settled in Villa Nova, the jurisdiction of Parenzo. As a reward for their devotion to Serenissima they

\footnotetext{
38 ASV, Senato Deliberationi Mar, registro 25, p. 51.

39 ASV, Senato Deliberationi Mar, registro 25, p. 51.

40 Apud. Antolini, Slavi et Latini in Istria.
} 
were "treated like all the other Venetian subjects"41, at least in theory. In fact, the local ministers took advantage of the settlers' status and exploited them. The Morlachs had to pay various unbearable taxes and were rubbed by the local soldiers. These were the reasons why they called for justice of the Doge to stop their deprivation of "money and their goods". The answer came from Venice in 18th March of the next year ${ }^{42}$. The document issued by the Senate asked the Podesta of Parenzo to apply and respect the following decisions:

In the first point: since the Morlachs asked not to pay anymore 14 ducats for the guards of the Parenzo's hinterland (the guards being those who applied the obligation) but 2 ducats like any other inhabitant of the region, the Senate granted this plea with a positive answer.

In the second request the Morlachs should receive exemption from the taxes the guards required for transiting the lands after night fall. The distance between the village and the lands the Morlachs cultivated was impossible to be crossed everyday only in daylight even if they did not leave the jurisdiction of Parenzo. They also complained about the guards who took the Morlachs cereals, aliments and animals as payment for trespassing public domains after night fall. The Senate exempted them from all of these obligations. With the third request the Morlach's jupan, involved in the protection of the Morlachs and the lands, is paid with the same amount like any other local leader in the region (any other jupan from Istria). The next two demands also received exemptions from other taxes invented and applied by local soldiers and tax collectors. The $6^{\text {th }}$ and $7^{\text {th }}$ requests target the pasturelands the Morlachs were supposed to use for their animals. Since the officials from Parenzo allowed anyone to use these pasturelands, including the citizens of the cities, affecting the Morlachs activities, the Senate recalled to these officials that "in the pasturelands used by the Morlachs animals cannot be brought from other places, since the Morlachs cannot feed their sheep in other places than those established by law"43. With the $8^{\text {th }}$ request the Morlachs from the hinterland of Parenzo can"slaughter their animals and prepare the meat the way they like" and "sell it without the payment of a tax, like the other inhabitants from Parenzo's villages ${ }^{44 "}$.

All these requests allow us to observe not only the manner in which Venice understood to attract the Morlach colonists in its emptied lands from Istria, but also how

${ }^{41}$ ASV, Senato Deliberationi Mar, filze 19 without number: presented by the Morlach emissaries in Venetian Senate in 30 October 1557.

42 ASV, Senato Deliberationi Mar, filze 19 without number: issued by the Venetian Senate in 18 March 1558.

${ }^{43}$ ASV, Senato Deliberationi Mar, filze 19 without number: Circa il sesto, per leze et ordeni etiam: Che nelle pascoli, che spettano et loro Murlachi non sia permesso andar a pascolar animali forestieri del alieni paese se non quelle che per leze et ordine e statuito poter stat in herbadego.

${ }^{44}$ ASV, Senato Deliberationi Mar, filze 19 without number: the Morlachs document: Tutti li altri de Istria puoleno fra loro amazare animali et fare della carne per sui bisogni et vivere in ogni tempo et similmente venderle del vivo senza alcun datio tamen essi poverini sono aspretti per tenati etiam; the document of the Senate: Circa l'ottavo et ultimo, tutti li altri se debba osservar quello che si osserva nello altre ville sottoposte a Parenzo. 
Serenissima managed to control the relationship established between the new inhabitants and the old ones. The main challenges appeared when the Morlach personality met the Istrian life-style. All the benefits and advantages the Morlachs received for their settlement in Istria proved to be enough for their obedience to the Republic only for a short period of time. After their Arrival in Istria, these new settlers complained about the difficulty they had in the settlement process and asked repeatedly to have extended exemptions and also new privileges. Usually, they based their demands on some aspects concerning the impediments raised by the city inhabitants of Istria, the privileges the Morlachs used to have living under the Ottoman administration and the Uskok neighbourhood, equally being dangerous and but yet attractive.

In the first place, the problematic relationship built between the new settlers, the Morlachs, and the ancient inhabitants had as a main cause the presence and the benefits the newly arrived obtained from the State. The discomfort felt by the Istrians reminds to some extent the ancient complaints recorded by the inhabitants of the Dalmatian cities: the Morlachs exploited their lands and used for themselves all the profits. Now new remains only the geographic context, the reason for which the Venetian Senate searched for similar solutions: the newly arrived had to use the public lands. Using the public lands (agricultural lands, pasturelands, forests, etc.) placed in a major part near the border with the Habsburgs; the Morlachs reduced the access of the locals. In addition to that, if one is to consider the fact that we speak about numerous successive migratory waves which changed the status of the inhabitants (new inhabitants became old inhabitants losing their benefits, and new settlers received the benefits had by the former new colonists ${ }^{45}$ ) the confusion and the discontent can be understood. Because of that, the Istrian citizens manifested their dissatisfaction by complaining about the diminishing commercial profit caused by the involvement of the Morlachs in the exploitation of the local resources. They also accused the Morlachs of the inobservance of their legal status conferred by the Republic or of their lack of organization and their different life-style.

A second aspect of the Morlachs requests addressed to the Republican Senate was based on the possibility of the return to Turchia. Like for the new Venetian subjects from Dalmatia, the Morlachs who settled in Istria promoted a similar thought of the return to the Ottoman territories. This idea was mainly based on their somehow privileged status which they had under the Turkish administration. There, in exchange for their military service, as part of the irregular troops, the Morlachs enjoyed a desired autonomy ${ }^{46}$. In this context, to avoid a new demographic decrease and a new process of colonizing new people, with all costs and efforts, Venice continued to offer to the

45 The idea is explained in a very useful manner by Antolini in Slavi e Latini in Istria.

${ }^{46}$ ASV, Senato, Deliberationi, Mar, filze 6, p. 409, without date but related to other documents from 1569: dicevo a Vostra Serenita che detti Murlachi al tempo che stavano in Turchia et che erano servi, overo membri principali delli confini turcheschi di Dalmatia erano da doa millia fuoghi et in ogni importante factioni et imprese che li turchi haveano da far voleriano che noi Murlachi fusamo li prima come e noto regulo per esser molto ben noto a Turchi la probita et valor nostro nella guerra. 
Morlachs positive answers. On the other hand, the concern of Serenissima focused the efforts of making the Morlachs to respect the limits of the territories they received to settle in, to live in a unified community and to respond in an obedient manner to the obligations and duties required by the State.

The third idea which encouraged the Morlachs to ask the Serenissima for reconfirming or re-granting them some benefits and privileges was based in the vicinity with the Austrian protégés, the Uskoks. The two aspects of this neighbourhood made the Morlachs determined to maintain a distant attitude toward the Venetian policy. On one side the Uskok life-style, based on independence, opportunities of piracy and the struggle against the Turks and also the common intervention of the House of Austria in excusing them for different damage done in other parts than against the Ottomans offered the Morlachs who settled in Istria an alternative to the life inside the Venetian state. On the other side the Venetian manner in punishing those guilty of murders or other atrocious crimes by banishing them from living inside the Venetian territory ${ }^{47}$ did not let them have any other option than to become Uskoks ${ }^{48}$. Considering these two aspects Venice had to attract and convince the Morlachs to be good Venetian subjects and even to negotiate with the Austrian authorities not to accept any Morlach fugitives from the Venetian territory ${ }^{49}$.

This way we can observe two parallel dialogues, one between the Morlachs and the state institutions, and another between the Morlachs and the inhabitants of the coastal cities. Moreover, these parallel dialogues confirm the colonist status of the Morlachs: they answered only in front of the central authorities. If one is to consider the many problems that appeared between the Morlachs and the city inhabitants (ancient inhabitants, land owners), these situations were solved in numerous phases. In first place, the complaints were presented in front of the count and captain of the city in which jurisdiction the unfortunate event took place. From here the information about the conflict was sent to Venice, since the Molachs were the protégés of the State and there the Senate found the best solutions for all its subjects. Back in Istria, the Senates decisions were immediately applied as suggested by the count and captain, or by the leader of Raspo (in charge of the new settlers in Istria from 1556).

One document issued by the Venetian Senate in May 1548 put together all of the problems caused by the settlement of the Morlachs in the Istrian hinterland (Parenzo,

${ }^{47}$ ASV, Senato Deliberationi Mar, registro 26 p. 163v: che Gargato Ossenich Murlaco, imputato di esser con alcuni altri complici murlachi, violentemente in casa di uno official del detto loco a tempo di notte, (...) sia bandito di Cita Nuova et suo territorio et de tutte terre, et lochi della Signoria Nostra, terrestri et maritimi, navilii, armati et disarmati, et di questa cita di Venetia et suo districto.

${ }^{48} \mathrm{Da}$ Minucio, Minuci, Historia de gli Uscochi, co i progressi di quella gente sino all' anno 1602, p. 15: "et questi non solo erano sudditi Turcheschi, ma di quelli anco del Dominio Veneto, ò fuggitivi delle galere, ò che temendo il meritato castigo de suoi delitti si retiravano a quell'Asilo".

49 ASV, Senato Deliberationi Mar, registro 27, pp. 104v - 106v: che non si manchera di operar col Serenissimo Re de Romani, et far ogni opportuna provisione, accio che le detti Murlachi banditi non habbiano commodita di venir a far danni, ne i territorii nostri. 
Puola, Sanlorenzo, Dignan, Dovigno, Valle, et Do castelli ${ }^{50}$ ). With this document the Senate helped the local leaders to establish the limits of the local security and resources that should be used by the indigenous citizens and by the Morlachs. The document set the prices for animal acquisitions in accord with their provenience and dimension, trade was always realized with a license from the count and captain ${ }^{51}$ and also the punishment for the Morlachs who proved to be guilty in various crimes. According to this document the Morlachs found guilty of stealing animals or other things should return them ${ }^{52}$ and if they committed murder the guilty party should be banished from all of the Venetian lands ${ }^{53}$. Moreover, the document included a complaint against the Morlach practice of revenge or vendetta - the Morlach Vrašba. Apparently this specific form of justice, seen as element of autonomy and separation from the state institutions, affected the efforts of the administrative assimilation of these new inhabitants of Istria ${ }^{54}$. The decision of the Senate was in accord with the citizen's request being aware of the danger represented by an increased autonomy for the Morlachs and established a set of punishments meant to remind all those who would ever resort

50 ASV, Senato Deliberationi Mar, registro 27, pp. 104v-106v; the document was also analyzed by Lia de Luca in her PhD thesis Lia de Luca, Venezia e le immigrazioni in Istria nel Cinque e Seicento, unpublished, defended at $\mathrm{Ca}^{\prime}$ Foscari University, Venice, 2011.

51 Ibidem: Al secondo che sia concesso quanto dimandano delle animali gross, delle minuti veramente da doi ... tantum con condicione, che li venditori per il dar in nota delli animali alle cancellarie, et per la licentia di poterli vender non sentamo gravezza, ne siano astretti a pagar cosa alcuna et dover le cancellarie siano lontane a miglia la volta, et licentia sopradetta siano fatte dalli Merighi delle ville.

52 Ibidem: altramente che essi Murlachi debbiano pagar de li loro proprii beni li animali, et robbe robbatem cioe li Murlachi de cadaun territorio quelle animali, et robbe, che serano tolte in quel territorio, dove essi habiterano, accio che li sia dato causa de obviar a i latrocinii, et di scoprir, et ritrovar i ladri, per che se vede minifestamente, che essi Murlachi quasi mai vengono robbati, et se alcuna cosa li vien tolta, ritrovanno de fatto per la cognition et pratica, che hanno delle ladri, altramente mancando questo singular remedio, non sera possibile, chi li supplicanti possino tenir ne animali, ne altro fuori alle campagne, ne piu potiamo viver con le povere loro fameglie.

53 Ibidem: Che tutti quelli, che sono et che sarano de ceteror bandti in ditta Provincia per ladri, asassini, et per altri casi atroci, et di mala qualita per dar recapito, et accettar banditi de simil sorte siano, et se intendano banditi de tutte le citta, castelli, luoghi, et territorii di Vostra Serenita della ditta provincia accio che in ciascun loco di quelli, dove fossero trovati possino esser impune offesi, et presi con il beneficio, et taglie statuite dalle leze, et per le soe condennation (..) Al quatro che sia conceso quanto dimandano per asassinamenti tantum et casi atroci et enormi di mala qualita.

54 Ibidem: Perche ditti perfidi Murlachi hanno una diabolica consuetudine tra loro di chiamar la Vrasba, che e una congiuratione, et sacramento di vendeta, che connintendono, che alcuno li habbi accusati, over testimoniato contra de loro o habbi agiutato a prendergli, et altre simil ingiurie, che li fosse fatte se ben con ragione, et astretto da li magnifici rezzori alcuno facesse simil operatione quello, che se non offeso, overo le padri, et fratelli cava fuori la spada, dove sia molsitudine di Murlachi et con giuramento chiama la vendeta, invitando lor parenti, amici et ben voglienti, ad offender et amazzar quello, over quelli, che li hanno ut supra offesi, la quar vrasba, et congiuration e molto temuta da cadauno et da lor murlachi principalmente, ita che per essaminatione, per giuramento mai volevo dir la verita, ne discoprir li ladri, pero se supplica, che nostra Serenita con severissime pene voglia prohibir tal destanda loro consuetudine, et che non ardiscano di menazzar, ne offender alcuno per accusation, ne per testimonio, over per agiutarli a prender, ne per altro ponendo freno alli lor diabolic costumi. 
to this form of revenge that justice arrived only from the Doge ${ }^{55}$. This kind of document was quite numerous, the fact which demonstrates the administrative struggle with the inclusion of the Morlach population, the new colonists, in its system and in decreasing the differences with the previous inhabitants. These efforts are once more proved by the documents published in 1885 in"Atti e memorie Della Societa Istriana di Archeologia e storia Patria" by Caenazzo Tomasso. In his article ${ }^{56}$ the author collects a series of documents issued equally in the name of the Morlachs representatives and city inhabitants and by the Senate during 1525 and 1596. All these documents put forward some demands, complaints, decisions and suggestions meant to facilitate the settlement and organization of the Morlachs in the territory of Rovigno, in the region of Lake Verzo. This Acta Capitularia contra Murlachos, as it was named by the author, included similar decisions like those presented in the already mentioned documents of October 1557, March 1558 and May 1548 completing this way our perspective over the Venetian efforts in the settlement of the Morlachs in Istria.

As we can observe in the case of the Morlachs brought by Alvise Badoer from the Turkey and transferred to Istria and in other examples presented, Venice took care that the Morlachs did not lack anything. The new colonists were exempted from paying taxes; they received financial loans for seeds, animals and house buildings, loans that in most cases were not paid back. At the same time the state authorities involved themselves in the government of the settlements and in the supervision of the eventual conflicts between the new and the old inhabitants. In this way there appeared some specific offices which influenced the character of the settlers' s communities: to stay gathered in villages, to live in the offered area and not to build new villages in isolated places without the consent of Venice. They also had to elect a leader that had to represent the authority and grant public order in his community.

In 1556 when the office of public goods was organized (illiterate goods) and which charged to the colonists and land distribution, the leader of Raspo was the one responsible for land distribution and for solving the conflicts in those new communities. As documents shows, the leader of Raspo had a very difficult responsibility in the accommodation of the Morlachs as new inhabitants of Istria. He (as the authority, and not like a person) was involved in correcting the behaviour of the Morlachs who had settled in Lovarigo, Stignano, S. Marena of Cranizza (1520) and in Polesana (1544) which did not show any respect for the local inhabitants ${ }^{57}$. There were also various

55 ASV, Senato Deliberationi Mar, registro 27, pp. 104v-106v; Al sexto che sia commesso alli rettori nostri dell'Istria, che essendo querelato, et giustificato sufficientemente contra alcun Murlaco di haver chiamato la vrasba, overo haver menacciato, et offeso alcuno, per haver accusato, et testimoniato contra Murlachi, overo agiutato in prender alcuno di loro possano dargli fino a tre tratti di corda et tenerlo in pregione, o bandirlo del suo territorio per mesi sei, et quello che chavera la spada, et sara principal auttor sia banditi per anni $X$, oltra la corda.

56 Can. Caemazzo Tomaso, I Morlacchi nel territorio di Rovigno, in "Atti e memorie della Societa Istriana di Archeologia e storia Patria”, vol I, fasc. I - II, Parenzo 1885, pp. 129.

57 Antolini, Slavi e Latini in Istria. 
local leaders named podesta that were charged with the supervision of the Morlachs. These podestas in their turn had to impose on these new-comers named with the common name of the Morlachs to give up their wild and predatory behaviour, and to form a unified community ${ }^{58}$.

The challenges met by Venice in the settlement of the Morlachs in Istria were various and numerous. Even if a policy of land distribution existed and organization of the new settlers, the Republic had to find the best solutions in controlling and improving the relations between the inhabitants, old and new, from villages and cities, officials and misbehaved peasants. If one considers the old habits, brought with them from Dalmatia like the refusal to answer in front of the justice system or to denounce a Morlach guilty of a specific crime, the hiding of the offender in the houses of relatives or in Austria or the Morlach form of vendetta (Vrašba) we can easily understand why the challenges were so difficult. Even though with its rich experience in controlling the Morlach incursions in Dalmatia, Venice proved to be very creative in finding solutions and in transforming the Morlach migrations into a success. In time the Morlach families adapted themselves to the Venetian administrative system from Istria gaining the respect and consideration of local leaders ${ }^{59}$. Moreover, this adaptability was once again proved by the name of Morlacchia Istriana, as a nucleus of the new settlers brought from Dalmatia and beyond its borders.

\footnotetext{
58 Caemazzo, I Morlacchi nel territorio di Rovigno, 129.

${ }^{59}$ Lia de Luca, Venezia e le immigrazioni, 213.
} 